\title{
Watershed discretization based on multiple factors and its application in the Chinese Loess Plateau
}

\author{
Y. D. $\mathrm{Xu}^{1}$, B. J. Fu ${ }^{1}$, C. S. $\mathrm{He}^{2}$, and G. Y. Gao ${ }^{1}$ \\ ${ }^{1}$ State Key Laboratory of Urban and Regional Ecology, Research Center for Eco-Environmental Sciences, \\ Chinese Academy of Sciences, P.O. Box 2871, Beijing 100085, China \\ ${ }^{2}$ Department of Geography, Western Michigan University, Kalamazoo, MI 49008-5054, USA
}

Correspondence to: B. J. Fu (bfu@rcees.ac.cn)

Received: 29 September 2011 - Published in Hydrol. Earth Syst. Sci. Discuss.: 10 October 2011

Revised: 22 December 2011 - Accepted: 27 December 2011 - Published: 9 January 2012

\begin{abstract}
The spatial discretization of watersheds is an indispensable procedure for representing landscape variations in eco-hydrological research, representing the contrast between reality and data-supported models. When discretizing a watershed, it is important to construct a scheme of a moderate number of discretized factors while adequately considering the actual eco-hydrological processes, especially in regions with unique eco-hydrological features and intense human activities. Because of their special lithological and pedologic characteristics and widespread man-made vegetation, discretization of watersheds in the Loess Plateau in Northern China is a challenge. In order to simulate the rainfall-runoff process, a watershed in the Loess Plateau, referred as Ansai, was spatially discretized into new units called land type units. These land type units were delineated under a scheme of factors including land use, vegetation condition, soil type and slope. Instead of using units delineated by overlaying land use and soil maps, the land type units were used in the Soil and Water Assessment Tool (SWAT). Curve numbers were assigned and adjusted to simulate runoff, using the US Natural Resources Conservation Service (NRCS) curve number method. The results of the runoff simulation better matched actual observations. Compared to the results that used the original units, the coefficient of determination $\left(R^{2}\right)$ and the Nash-Sutcliffe coefficient $\left(E_{\mathrm{NS}}\right)$ for monthly flow simulation increased from $0.655-0.713$ and $0.271-0.550$ to $0.733-0.745$ and 0.649 0.703 , respectively. This method of delineating into land type units is an easy operation and suitable approach for ecohydrological studies in the Chinese Loess Plateau and other similar regions. It can be further applied in soil erosion simulation and the eco-hydrological assessment of re-vegetation.
\end{abstract}

\section{Introduction}

Watersheds are commonly spatially discretized in ecologic and hydrological studies. The purpose of spatial discretization is to objectively represent the differences in ecological or hydrological characteristics that exist within the watershed (Kumar et al., 2010; Hellebrand and van den Bos, 2008). By using spatial discretization, a watershed is divided into units, which are treated as statistical objects or calculated units for statistical analysis or simulation. Spatial discretization can be regarded as a tradeoff between reality and a model represented by supported data. The more discretized factors and more detailed discretization, the more reliably the discretization represents the true watershed (Das et al., 2008); however, at the same time, more physical mechanisms and data are needed. Over-parameterization and scaling problems also take effect (Doherty, 2003), so it is crucial to select a moderate number of discretized factors with major influences on the eco-hydrological processes, and have plenty of data and theory to support the discretization.

Spatial discretization most commonly divides a watershed into hydrological response units (HRUs). The crucial assumption for HRU discretization is that the hydrological characteristic variation within a HRU must be little compared to the dynamics in different HRUs (Flügel, 1995). The parameters within each HRU should be uniform. HRUs are generated by overlaying maps of selected factors.

Based on existing theories and experimental data, researchers can construct a scheme of delineated factors and calculate or simulate the eco-hydrological processes within each HRU. A typical approach for HRU delineation is the combination of land use and soil types (Beldring et al., 2003; Das et al., 2008), which can be seen in a multitude 
of research and some hydrological models, including the Erosion Productivity Impact Calculator or EPIC (Williams, 1995), SWRRB (Williams et al., 1985; Arnold et al., 1990), Soil and Water Assessment Tools or SWAT (Arnold et al., 1998), etc. Other factor combinations that have been used to determine HRUs are the combinations of land use, topography and aquifers (Blöschl et al., 2008), the combinations of slope, aspect, elevation, soil particle size, soil water holding capacity and vegetation (Legesse et al., 2003), etc.

As far as runoff is concerned, to account for the lack of sub-daily meteorological data, physical soil properties and the physiological attributes of plants, the Soil Conservation Service (now the Natural Resources Conservation Service, NRCS) curve number method (NRCS, 1972) is the most common method for predicting runoff volume (Arnold et al., 1998; Mishra and Singh, 2004; Garen and Moore, 2005). It is an empirical method developed by the US Department of Agriculture based on measured precipitation and runoff. Accompany with this method, HRUs were delineated by the combination of land use and soil types, then the curve number of each HRU is determined according to land use, its hydrological condition (mostly represented by ground coverage), as well as the soil's hydrological group.

The hydrological condition of the vegetation is an important factor in determining the curve number for an HRU (NRCS, 1986). In existing studies, the HRU curve numbers with the same vegetation type and the same soil hydrological group are uniform, creating an assumption that the hydrological conditions for certain vegetation within the study area are the same. This assumption does not hold true in some studies, especially in some regions intensely influenced by human activities, exhibiting fractured vegetation patterns.

Hydrological processes are also dramatically affected by slope. The curve numbers obtained from the NRCS handbook (NRCS, 1986) are usually assumed to correspond to a slope of $5 \%$. Most studies do not account for the slope when determining the CN. Some hydrological models (e.g. SWAT) allow users to adjust CNs by slope. The adjustment, however, must be done prior to inputting the curve numbers, and according to the average slope in the study area. If the slope factor is excluded, there are many disadvantages using the $\mathrm{CN}$ method, especially in some regions with various landforms and steep slopes. Some attempts have modified curve numbers by slope (Williams, 1995; Huang et al., 2006). Using slope as a factor for HRU delineation and adjusting the curve numbers accordingly would be helpful for runoff simulation.

The Chinese Loess Plateau is a region with fractured vegetation pattern and steep slopes (Huang et al., 2006; Fu, 1989). In the plateau's Yanhe watershed, for example, the average slope is $23.4^{\circ}$. Vegetation in the Chinese Loess Plateau is intensely influenced by human activities including reclamation, abandonment, afforestation, etc. (Fu et al., 2006, 2009; Li et al., 2009). Before the 1970s, sloping cropland and natural grassland were the two dominant land use types. After the 1970s, several conservation projects were enforced in order to control soil erosion. Consequently, the landscape has been intensely adjusted by the redesigned land use patterns. Various vegetation types, including natural forest, planted forest, natural shrubland, planted shrubland, natural grassland, artificial grassland and cropland constitute a mosaic landscape pattern. The hydrological condition of the vegetation, using coverage as an indicator, is influenced by several environmental factors, such as climate, topography (slope, aspect, etc.), soil (soil organic matter, soil moisture, etc.) and so on. Nonnative vegetation coverage is also affected by age and some human factors, such as plant density and maintenance measures. Even within a watershed, the hydrological condition of the vegetation varies immensely.

Because of the lack of data of the aforementioned factors, especially plant age and human factors, quantification or simulation of the coverage of the vegetation in the Chinese Loess Plateau is difficult. Remote sensing data is relatively easy to access and time-efficient. The vegetation indices derived from remote sensing images, such as the normalized difference vegetation index (NDVI), are commonly used to retrieve vegetation coverage (Zribi et al., 2003; Leprieur et al., 1994). This is more reliable than simulation methods to determine the hydrological condition of the vegetation in the Loess Plateau.

A subwatershed in the upstream section of the Yanhe watershed in the Loess Plateau is the study area for this research. The area was spatially discretized into new units called "land type units" (units with relatively homogenous land use and environmental factors), a flexible concept employed by several researchers (Gustafson et al., 2004; Kupfer and Franklin, 2000; Rykken et al., 1997). The land use type, soil type, hydrological condition of vegetation and slope were all included as discretizing factors for delineating the land type units. The hydrological condition of the vegetation was determined by coverage retrieved from NDVI. The curve numbers of the land type units were determined by land use type, hydrological condition of vegetation and the soil's hydrological group, then further modified by slope. The monthly runoff processes were simulated by SWAT in periods near remote sensing image acquisition date. The results were compared with initial unit results. Also discussed is the advantages and further application of land type units.

\section{Materials and methods}

\subsection{Study area}

The Yanhe watershed $\left(108^{\circ} 38^{\prime}-110^{\circ} 29^{\prime} \mathrm{E}, \quad 36^{\circ} 21^{\prime}-\right.$ $37^{\circ} 19^{\prime} \mathrm{N}$ ) lies in the middle of the Loess Plateau in the northern Shaanxi Province and covers an area of $7725 \mathrm{~km}^{2}$ (Fig. 1). The subwatershed in this study is located in the upstream section of the Yanhe, controlled by a hydrometric station named “Ansai" $\left(109^{\circ} 19^{\prime} \mathrm{E}, 36^{\circ} 52^{\prime} \mathrm{N}\right)$, and as a matter 


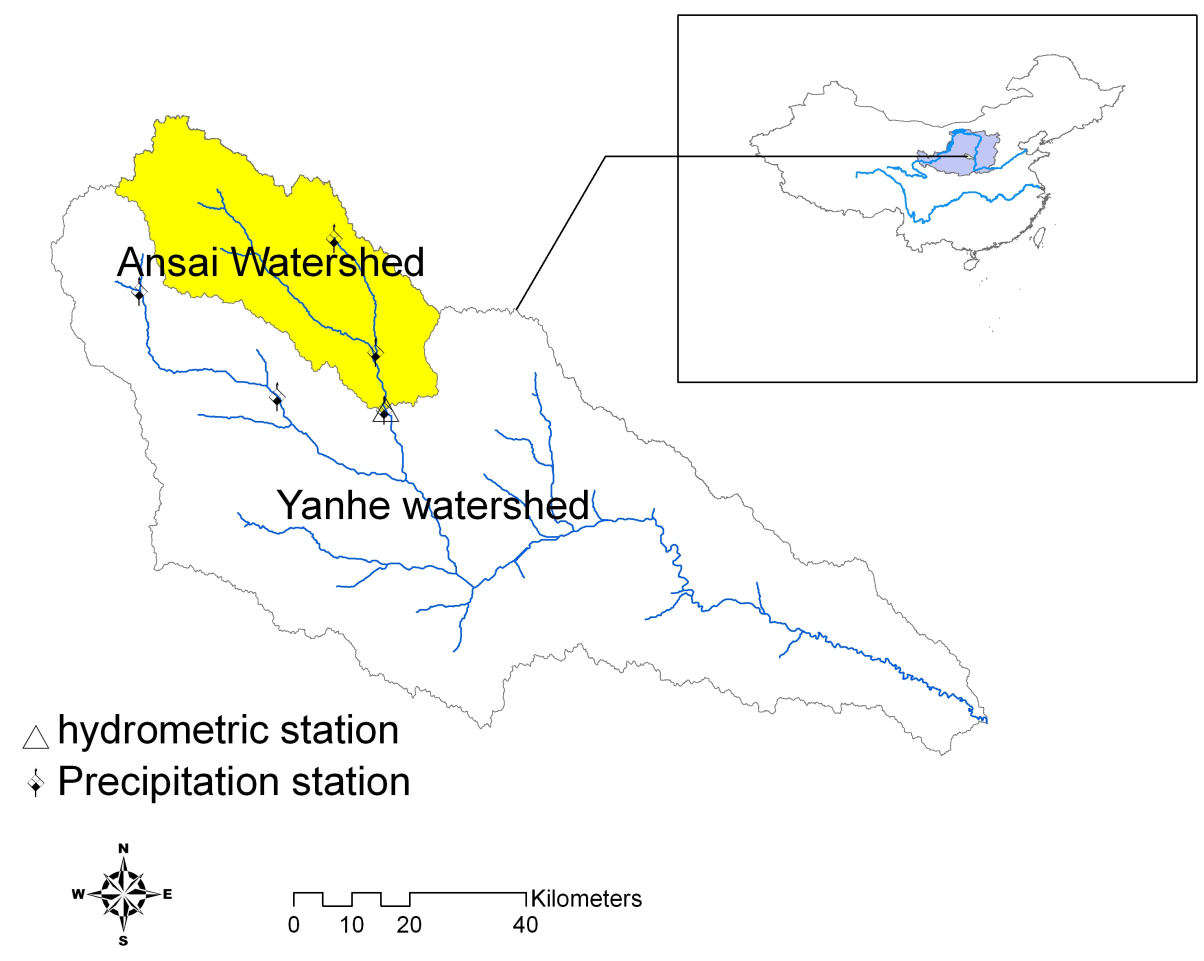

Fig. 1. Study area and the distribution of hydrometric station and precipitation stations.

of convenience, it is referred to as the Ansai watershed. The area is $1334 \mathrm{~km}^{2}$ with an average slope $23.9^{\circ}$. It has a typical semiarid continental climate with an average temperature of $8.8^{\circ}$ and an average annual precipitation of $505 \mathrm{~mm}$. Rainfall shows high seasonal variability, with more than $60 \%$ of the annual precipitation occurring between July and September. The landform is a typical loess hilly-gullied landscape with elevations ranging from $1057 \mathrm{~m}$ to $1743 \mathrm{~m}$ above sea level, with an average of $1362 \mathrm{~m}$. Covering $86.4 \%$ of the watershed, loess soil, derived from loess parent material, is dominant.

Prior to conservation projects, sloping cropland and natural grassland were the two dominant land use types in the Yanhe watershed. After the 1970s, cropland abandonment and re-vegetation was implemented, dramatically changing the land use pattern. Croplands declined while forest shrubland and grassland expanded. Various land use types constitute a mosaic landscape pattern. Even along a slope surface, the landscape structure is often fragmentized. The major crop species are maize (Zea mays L.), potatoes (Solanum tuberosum L.), beans (Phaseolus vulgaris L.) and millet (Panicum miliaceum L.). The grassland is dominated by Gmelin Sagebrush (Artemisia gmelinii Web. ex Stechm.), Argy Sagebrush (Artemisia. argyi Levl. et Vant.) and Bunge Needlegrass (Stipa bungeana Trin.). The forests are mainly manmade and comprise of Black Locust (Robinia pseudoacacia L.). The shrubland is dominated by Intermediate Peashrub (Caragana Intermedia Kuang et $\mathrm{H}$. C. Fu), Sandthorn (Hippophae rhamnoides L.) and Vetchleaf Pagodatree (Sophora viciifolia Lindl.).

\subsection{Data sets}

Land use type, soil type, topographical, meteorological, and hydrological data of the Ansai watershed, as well as satellite imagery, were collected for this research.

A year 2000 land use map (1:50000 scale) was interpreted by the Institute Of Remote Sensing Applications, Chinese Academy of Sciences from remotely sensed Landsat TM images. Six land use types were identified: forest, shrubland, grassland, cropland, water bodies and residential areas.

A soil survey map (1:10000 scale) was provided by the Institute of Soil and Water Conservation, Chinese Academy of Sciences. The soil types were divided into four categories: dark-purple loess soil, loess soil, red clay soil and alluvial soil.

A $25 \mathrm{~m}$-resolution digital elevation model (DEM) for the watershed, derived from a 1:50000 scale contour map, was supplied by the National Geomatics Center of China. The slope was calculated using the DEM.

Meteorological and hydrological data of 1995 to 2002 were collected. Daily data from five precipitation stations in or near the Ansai watershed and the daily flow data of Ansai hydrometric station were collected from the Hydrology and Water Resources Investigation Bureau in Yanan City. The daily precipitation data, maximum and minimum 
temperatures, average wind speeds and relative humidity of the Yanan $\left(109^{\circ} 30^{\prime} \mathrm{E}, 36^{\circ} 36^{\prime} \mathrm{N}\right)$ and Wuqi $\left(108^{\circ} 10^{\prime} \mathrm{E}\right.$, $\left.36^{\circ} 55^{\prime} \mathrm{N}\right)$ meteorological stations was downloaded from China Meteorological Data Sharing Service System (http: //new-cdc.cma.gov.cn).

Landsat TM imagery of 17 October 1999 was downloaded from the International Scientific Data Service Platform of Chinese Academy of Sciences (http://datamirror.csdb.cn).

\subsection{Methods}

\subsubsection{Land type units delineation}

Land type units for the Ansai watershed were delineated by a factor scheme including land use and soil type, the hydrological condition of vegetation and slope. These four factors were determined as follows:

According to the US National Engineering Handbook (NRCS, 1986), land use was reclassified into the following categories: woods, brush, grassland, straight row crops, water and residential districts.

The hydrological groups of the four kinds of soil were determined according to the infiltration rate, texture and clay layer of the soil. Other properties of each soil were obtained from field sampling investments and supplemented by soil survey data, data from prior research and estimations of the empirical model Soil-Plant-Air-Water (SPAW) Soil Water Characteristics (Saxton, 2002).

The determination of the hydrological condition of vegetation included the following three steps:

(1) calculation of the normalized difference vegetation index (NDVI). NDVI is defined as the normalized ratio of the near infrared reflectance response to the red response of a surface. It was calculated as:

$\mathrm{NDVI}=\frac{R_{\mathrm{nir}}-R_{\mathrm{red}}}{R_{\mathrm{nir}}+R_{\text {red }}}$

where $R_{\text {nir }}$ is the reflectance at the near infrared band, and $R_{\text {red }}$ is the reflectance at the red band. In this study, band 4 (infrared) and band 3 (red) of the Landsat-TM imagery were used for the NDVI derivation.

(2) Vegetative coverage inversion using NDVI. Vegetation coverage of the watershed was inversed by NDVI using a dimidiated pixel model (Leprieur et al., 1994; Zribi et al., 2003). The main formula of this model is:

$f_{\mathrm{c}}=\frac{\mathrm{NDVI}-\mathrm{NDVI}_{\text {soil }}}{\mathrm{NDVI}_{\mathrm{veg}}-\mathrm{NDVI}_{\text {soil }}}$

where $f_{\mathrm{c}}$ is vegetation coverage expressed as fraction; NDVI is the value of NDVI for the image cell; NDVI soil $_{1}$ is the value of NDVI for bare soil; $\mathrm{NDVI}_{\mathrm{veg}}$ is the value of NDVI for full-covered vegetation. $\mathrm{NDVI}_{\text {soil }}$ and $\mathrm{NDVI}_{\text {veg }}$ was set to the value of NDVI at which the cumulative frequency was $5 \%$ and $95 \%$, respectively.
Table 1. The relationship between hydrological condition and vegetation coverage.

\begin{tabular}{cc}
\hline hydrological condition & vegetation coverage \\
\hline good & $>75 \%$ \\
fair & $50 \%$ to $75 \%$ \\
poor & $<50 \%$ \\
\hline
\end{tabular}

(3) Determination for hydrological condition using vegetation coverage. The relationship between the hydrological condition and vegetation coverage, based on the National Engineering Handbook (NRCS, 1986), is shown in Table 1. However, this relationship is only applicable for woods, brush and grassland. The hydrological condition of water and residential districts was not considered necessary. For crops, the hydrological condition, written in the National Engineering Handbook, is "based on combination factors that affect infiltration and runoff, including (a) density and canopy of vegetative areas, (b) amount of year-round cover, (c) amount of grass or close-seeded legumes, (d) percent of residue cover on the land surface ( $\operatorname{good} \geq 20 \%$ ), and (e) degree of surface roughness" (NRCS, 1986). In the Ansai watershed, maize is the dominant crop, and there are no other plants in the corn fields. Little residue is left after harvest. These cropland factors impair infiltration and tend to increase runoff. As a result, all the cropland in Ansai watershed was considered to be in poor hydrological condition.

The curve number modification using slope was completed using the method developed by Mingbin Huang (Huang et al., 2006). The slope-adjusted NRCS $\mathrm{CN}_{2}$ $\left(\mathrm{CN}_{2 \text { slp }}\right)$ was calculated as:

$\mathrm{CN}_{2 \mathrm{slp}}=\mathrm{CN}_{2} \frac{322.79+15.63 \mathrm{slp}}{\mathrm{slp}+323.52}$

where $\mathrm{CN}_{2}$ is the initial curve numbers for an average soil moisture condition in the TR-55 manual, and slp is slope $\left(\mathrm{m} \cdot \mathrm{m}^{-1}\right)$.

In this study, slope was equally divided into three classes by the occupied area: (1) $0^{\circ}-19.38^{\circ}$, with an average of $12.32^{\circ}$; (2) $19.38^{\circ}-28.85^{\circ}$, with an average of $24.15^{\circ}$; (3) $>28.85^{\circ}$, with an average of $35.15^{\circ}$. The slope adjusted $\mathrm{CN}_{2 \text { slp }}$ for the three classes of slope are expressed in Table 2.

Land type units delineation was accomplished by combining the land use, soil, hydrological condition (as applicable for woods, brush, grassland and crops) and slope, as shown detailedly in Table 3 . There were at most $221(3 \times 3 \times$ $4 \times 5+1 \times 1 \times 4 \times 5+1 \times 1 \times 4 \times 5+1 \times 1 \times 1 \times 1)$ possible land type unit combinations. All the procedures were generated using ArcGIS 9.3, in which the four delineating factors' maps were overlapped into a new shapefile. The corresponding $\mathrm{CN}_{2} \mathrm{~S}$ for each land type unit were added to the database of ArcSWAT2009 (Winchell et al., 2010). 
Table 2. The three classes of slope and the expressions of the slope-adjusted $\mathrm{CN}_{2}$.

\begin{tabular}{cccc}
\hline $\begin{array}{c}\text { Slope } \\
\text { classes }\end{array}$ & $\begin{array}{c}\text { Average } \\
\text { slope }\end{array}$ & $\begin{array}{c}\text { Area percentage } \\
\text { in watershed }\end{array}$ & $\begin{array}{c}\text { expression of the } \\
\text { slope-adjusted } \mathrm{CN}_{2}\end{array}$ \\
\hline $0^{\circ}-19.38^{\circ}$ & $12.32^{\circ}$ & $33.33 \%$ & $\mathrm{CN}_{2 \mathrm{slp}}=1.008 \mathrm{CN}_{2}$ \\
$19.38^{\circ}-28.85^{\circ}$ & $24.15^{\circ}$ & $33.33 \%$ & $\mathrm{CN}_{2 \mathrm{slp}}=1.018 \cdot \mathrm{CN}_{2}$ \\
$>28.85^{\circ}$ & $35.15^{\circ}$ & $33.33 \%$ & $\mathrm{CN}_{2 \mathrm{slp}}=1.030 \cdot \mathrm{CN}_{2}$ \\
\hline
\end{tabular}

Table 3. Detail factors for land type unit delineation.

\begin{tabular}{|c|c|c|c|}
\hline Land use & Hydrological condition & Soil & slope \\
\hline $\begin{array}{l}\text { Woods } \\
\text { Brush } \\
\text { Grassland }\end{array}$ & Good, fair, poor & \multirow{3}{*}{$\begin{array}{c}\text { dark-purple loess soil } \\
\text { loess soil } \\
\text { red clay soil } \\
\text { alluvial soil }\end{array}$} & \multirow{3}{*}{$\begin{array}{c}0^{\circ}-19.38^{\circ} \\
19.38^{\circ}-28.85^{\circ} \\
>28.85^{\circ}\end{array}$} \\
\hline Crops & Poor & & \\
\hline residential districts & \multirow{2}{*}{ Not applicable } & & \\
\hline water & & Not applicable & Not applicable \\
\hline
\end{tabular}

\subsubsection{Rainfall-runoff process simulation}

The Soil and Water Assessment Tool (SWAT) (Arnold et al., 1998) was applied for rainfall-runoff process simulation in this study. It is a watershed scale model for simulating longterm runoff and nutrient losses from rural watersheds. In the hydrology module of SWAT, there are two methods for runoff simulation: the NCRS CN and the Green \& Ampt infiltration method. The former was applied in this research. The method used rainfall $P$ and a retention parameter $S$ to predict runoff $Q$, all expressed in $\mathrm{mm}$ :

$Q=\frac{(P-0.2 S)^{2}}{P+0.8 S}$ for $P>0.2 S$

$Q=0$ for $P \leq 0.2 S$

The retention parameter $S$ was calculated by:

$S=\frac{25400}{\mathrm{CN}}-254$

where $\mathrm{CN}$ is the curve number.

NRCS defines three antecedent moisture conditions: I-dry (wilting point), II-average moisture, and III-wet (field capacity). The corresponding curve numbers are $\mathrm{CN}_{1}, \mathrm{CN}_{2}$ and $\mathrm{CN}_{3}$. The values of $\mathrm{CN}_{2}$ are listed in the National Engineering Handbook (NRCS, 1986) for various land uses, managements, hydrological conditions and soil hydrological groups. $\mathrm{CN}_{1}$ and $\mathrm{CN}_{3}$ are calculated by $\mathrm{CN}_{2}$.

SWAT adjusts the daily curve numbers with soil profile water content or accumulated plant evapotranspiration.
When the former adjustment is applied, the following equation is used:

$S=S_{\max } \cdot\left[1-\frac{\mathrm{SW}}{\mathrm{SW}+\exp \left(w_{1}-w_{2} \cdot \mathrm{SW}\right)}\right]$

where $S$ is the daily retention parameter $(\mathrm{mm}), S_{\max }$ is the maximum value of the retention parameters $(\mathrm{mm}), \mathrm{SW}$ is the soil profile water content excluding the amount of water held in the profile at wilting point $(\mathrm{mm}), w_{1}$ and $w_{2}$ are shape coefficients. $S_{\max }$ is calculated by $\mathrm{CN}_{1}$ :

$S_{\max }=\frac{25400}{\mathrm{CN}_{1}}-254$

$w_{2}$ is a function of $S_{\max }, \mathrm{CN}_{3}$, soil profile water content at field capacity ( $\mathrm{mm}$ ) and soil profile water content when completely saturated; $w_{1}$ is a function of $S_{\max }, \mathrm{CN}_{3}$, soil profile water content at field capacity $(\mathrm{mm})$ and $w_{2}$.

When the daily retention parameter $(S)$ is adjusted with accumulated plant evapotranspiration, the following equation is used:

$S=S_{\mathrm{prev}}+E_{0} \cdot \exp \left(\frac{-\mathrm{cncoef}-S_{\mathrm{prev}}}{S_{\max }}\right)-R-Q$

where $S_{\text {prev }}$ is the retention parameter for the previous day $(\mathrm{mm}), E_{0}$ is the potential evapotranspiration for the day (mm), cncoef is the weighting coefficient for calculating the daily retention coefficient based on plant evapotranspiration, $R$ is the daily rainfall $(\mathrm{mm})$, and $Q$ is the surface runoff $(\mathrm{mm})$. 


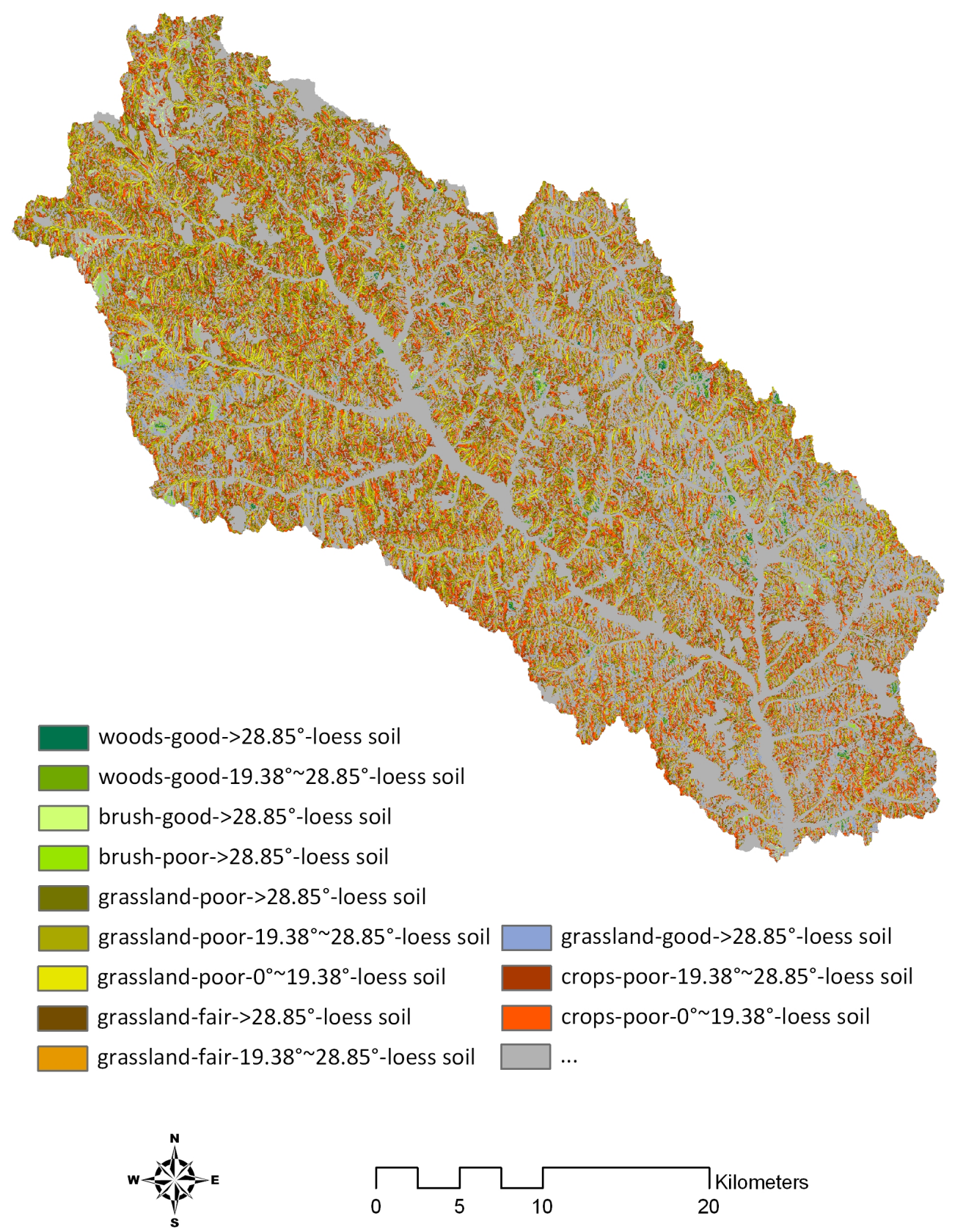

Fig. 2. Main land type units distribution within the Ansai watershed.

The daily curve number value is adjusted by the retention parameter calculated for that soil moisture content or accumulated plant evapotranspiration:

$\mathrm{CN}=\frac{25400}{S+254}$

All above is presented in the theoretical documentation of SWAT (Neitsch et al., 2005) in detail. Actually, for the determined relationship between the retention parameter $(S)$ and the curve number $(\mathrm{CN})$, the NCRS $\mathrm{CN}$ method is a one pa- rameter model. The typical curve number $\left(\mathrm{CN}_{2}\right)$ is the most important parameter for runoff simulation.

Before units delineation, watershed should be divided into subbasins in ArcSWAT. Because prior research has shown that the number of subbasins have little influence on runoff simulations (Jha et al., 2004; Tripathi et al., 2006), the Ansai watershed was divided into 21 subbasins, for when the number of subbasins was equal or greater than 21 , the rainfall data of all the five precipitation stations would be read by the model, otherwise some precipitation stations would be excluded. 
Table 4. Unit amounts and simulation results based on HRUs and land type units.

\begin{tabular}{lrrrr}
\hline $\begin{array}{l}\text { Discretized } \\
\text { units }\end{array}$ & $\begin{array}{r}\text { Threshold } \\
\text { for units } \\
\text { delineation }\end{array}$ & $\begin{array}{r}\text { Unit } \\
\text { amounts }\end{array}$ & $\begin{array}{r}E_{\mathrm{ns}} \text { for } \\
\text { monthly runoff }\end{array}$ & $\begin{array}{r}R^{2} \text { for } \\
\text { monthly runoff }\end{array}$ \\
\hline \multirow{3}{*}{ HRUs } & 0 & 256 & 0.550 & 0.713 \\
& 5 & 83 & 0.440 & 0.704 \\
& 12 & 60 & 0.271 & 0.655 \\
\hline \multirow{2}{*}{ Land type units } & 0 & 1547 & 0.703 & 0.744 \\
& 5 & 285 & 0.692 & 0.745 \\
& 12 & 85 & 0.649 & 0.733 \\
\hline
\end{tabular}

In each subbasin, discretized units were delineated. When the initial method was applied, the subbasins were discretized into HRUs defined by land use and soil. When the new discretization method was applied, the land type units were generated instead.

There were thresholds of "land use area percentage over subbasin", "soil class percentage over land use area" and "slope class percentage over soil area". Slope classification was not applied in this study. In order to exclude the influence of the discretized unit amounts on the runoff simulation, land use and soil thresholds were set to three values: 0, 5 and 12. The unit amounts based on these different thresholds are shown in Table 4.

Runoff of the Ansai watershed from 1995 to 2002 was simulated using SWAT. Discharges were observed daily at the Ansai monitoring center from April to October, but observed on fixed dates in other months. So the simulation results of these seven months per year were evaluated.

The purpose of this study was to compare the performance of Hydrological Response Units (HRUs) and land type units, so no calibration was performed for the model; that is, the influence of model parameters was excluded. The first three years (1995-1997) were used as a warm up period. Simulated monthly flow from April to October in 1998 to 2002 was evaluated against the observation.

The agreement between the simulated and measured flow was quantitatively evaluated using the coefficient of determination $\left(R^{2}\right)$ and the Nash-Sutcliffe coefficient $\left(E_{\mathrm{NS}}\right)$ (Nash and Sutcliffe, 1970), calculated as:

$$
\begin{aligned}
& R^{2}=\frac{\left[\sum_{i}\left(Q_{\mathrm{m}, i}-\overline{Q_{\mathrm{m}}}\right)\left(Q_{\mathrm{s}, i}-\overline{Q_{\mathrm{s}}}\right)\right]^{2}}{\sum_{i}\left(Q_{\mathrm{m}, i}-\overline{Q_{\mathrm{m}}}\right)^{2} \sum_{i}\left(Q_{\mathrm{s}, i}-\overline{Q_{\mathrm{s}}}\right)^{2}} \\
& E_{\mathrm{NS}}=1-\frac{\sum_{i}\left(Q_{\mathrm{m}}-Q_{\mathrm{s}}\right)_{i}^{2}}{\sum_{i}\left(Q_{\mathrm{m}, i}-\overline{Q_{\mathrm{m}}}\right)^{2}}
\end{aligned}
$$

where $Q_{\mathrm{m}}$ is the measured runoff, and $Q_{\mathrm{s}}$ is the simulated runoff.

\section{Results}

The Ansai watershed was divided into 177 kinds of land type units. The five dominant combinations (listed as: land use - hydrological condition of vegetation - slope - soil), totaling $32.91 \%$ of the watershed, were (1) crops - poor $19.38^{\circ} \sim 28.85^{\circ}$ - loess soil, (2) grassland - poor $->28.85^{\circ}-$ loess soil, (3) grassland - poor - $19.38^{\circ} \sim 28.85^{\circ}$ - loess soil, (4) crops - poor $-0^{\circ} \sim 19.38^{\circ}$ - loess soil and (5) grassland poor $-0^{\circ} \sim 19.38^{\circ}-$ loess soil. The dominant woodland type unit combination was woods - good $->28.85^{\circ}$ - loess soil. The dominant brushland type unit combination was brush good $->28.85^{\circ}-$ loess soil. The main land type units and their distribution is shown in Fig. 2.

The values of $R^{2}$ and $E_{\mathrm{NS}}$ for monthly flow, based on HRUs and land type unit discretization, are shown in Table 4.

Compared with the HRU simulation, the land type unit results were better. $E_{\text {NS }}$ improved from $0.271-0.550$ to 0.649 $0.703 ; R^{2}$ increased from $0.655-0.713$ to $0.733-0.745$. The observed and simulated monthly flow based on HRUs and land type units are shown in Fig. 3 (results for unit delineation thresholds equal to 0 were selected as example).

With the number of units increasing, the simulation coefficients decreased. The decreasing trend of HRU-based simulation efficiency was more apparent than that based on land type units.

\section{Discussion}

As the results demonstrated above, land type unit discretization helped the hydrological model simulate runoff better than the initial HRU discretization. Land type units, delineated by multiple factors, contributed to the determination of $\mathrm{CN}$ values, reducing the uncertainty of the parameters.

Altering $\mathrm{CN}$ values with the calibration of different parameters can also improve runoff simulation efficiency. In comparison, however, the determination of $\mathrm{CN}$ values based on land type units better represents the actual status. The eco-hydrological characteristic differences among land type 


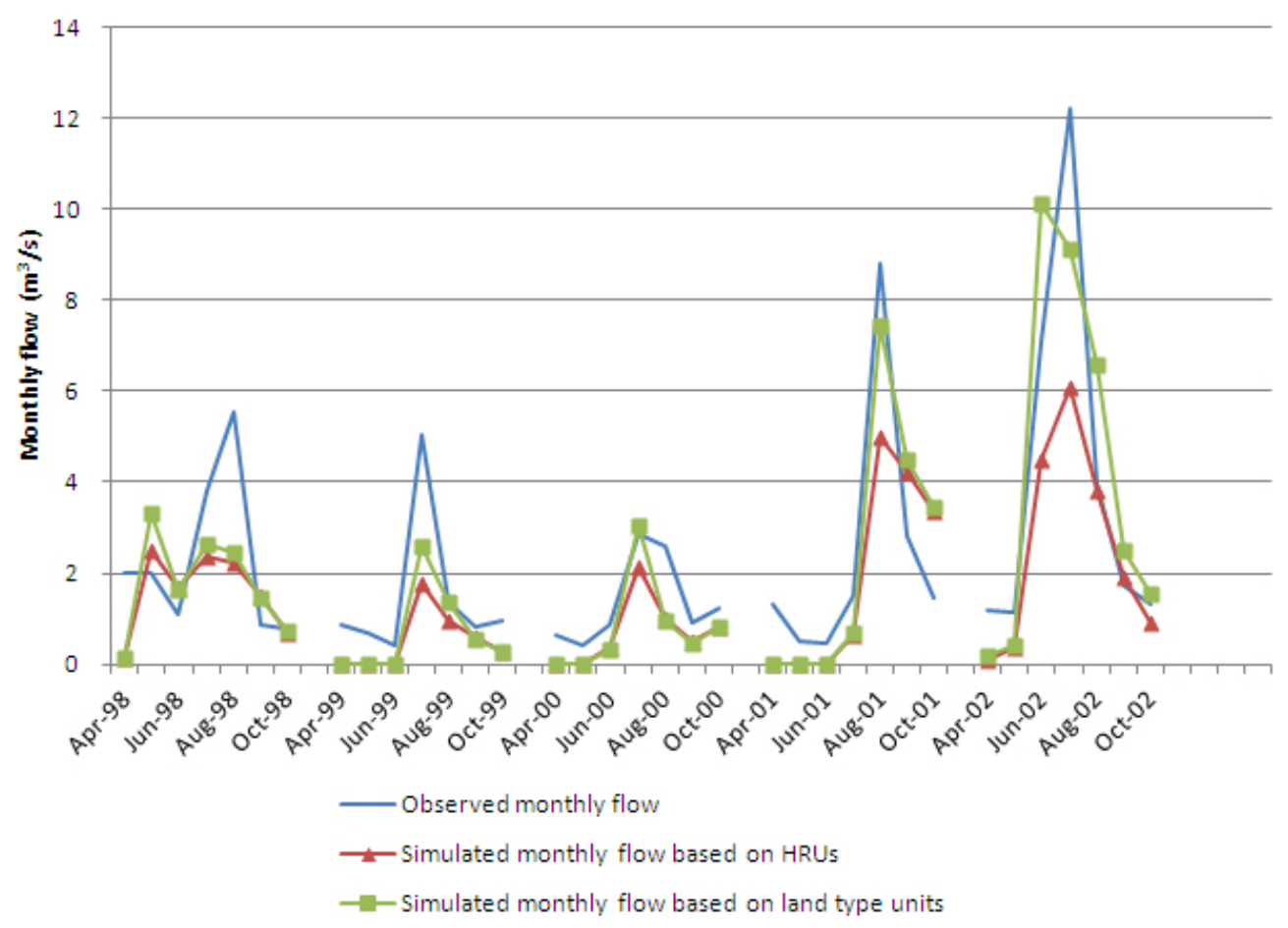

Fig. 3. Observed and simulated monthly flow.

units and subbasins can be indicated more accurately on the basis of land type unit discretization.

By means of remote sensing, the vegetation condition can be inversed and considered for an eco-hydrological simulation based on land type units. The hydrological process of vegetation on different slopes can also be better simulated, so the hydrological effect of land use changes can be more reliably reflected. This is helpful for assessing the revegetation projects (e.g. the Grain for Green project) in the Loess Plateau.

Land type units can also be applied to soil erosion simulation. Several types of erosion exist in the Loess Plateau, for instance, sheet erosion, rill erosion, gully erosion, gravitational erosion, etc. Lots of research has focused on the critical slope gradient and simulation of different erosion processes (Wu and Cheng, 2005; Valentin et al., 2005; Hessel and van Asch, 2003). Slope was taken into account in the land type unit delineation. Accompanied with the prior research, the land type units can be used to better simulate soil erosion.

Monthly discharges for April, May and October were commonly underestimated in the simulation of this study. Two probable reasons exist. Firstly, the base flow was not accurately simulated. Secondly, the curve numbers for these months were higher than the exact status. In the study area, April and May are the early period of growing season. Most crops are not planted until the end of May. As for October, it's a declining period for plant growth, as well as the harvest time for crops. Though the plant growth cycle and interception is simulated in SWAT, there may be some deviation in curve number adjustment and canopy storage simulation in initial and last growing season in this study. Assigning curve numbers for agricultural lands, especially cultivated lands separately for different growth period may solve this error.

\section{Conclusions}

Land type units were delineated for the spatial discretization of a watershed in the Chinese Loess Plateau. The discretized factors were composed of land use and soil types, the hydrological condition of vegetation and slope.

The runoff curve number for each kind of land type unit was defined by land use type, soil type and the hydrological condition of vegetation (according to the National Engineering Handbook) and modified by slope.

The runoff processes of the studied watershed were simulated by Soil and Water Assessment Tools (SWAT), in which the NRCS curve number method was applied. When the initial HRUs were used for the spatial discretization of the watershed, the coefficient of determination $\left(R^{2}\right)$ and the NashSutcliffe coefficient $\left(E_{\mathrm{NS}}\right)$ for the monthly flow simulation were $0.655-0.713$ and $0.271-0.550$, respectively. When land type units were used for the spatial discretization of the watershed, the simulation efficiency was improved. $R^{2}$ and $E_{\mathrm{NS}}$ for the monthly flow simulations were $0.733-0.745$ and $0.649-0.703$, respectively. 
Compared to the initial HRU discretization, the land type units help to determine the $\mathrm{CN}$ value and more accurately represent the actual status. This is a suitable approach for eco-hydrological studies in the Chinese Loess Plateau and similar regions. This method can be further applied to soil erosion simulations and the eco-hydrological evaluation of land use changes in the Chinese Loess Plateau.

Acknowledgements. This research was supported by the National Natural Science Foundation of China (no. 40930528), the External Cooperation Program of the Chinese Academy of Sciences (No. GJHZ0948) and the CAS/SAFEA International Partnership Program for Creative Research Teams of "Ecosystem Processes and Services."

Edited by: J. Liu

\section{References}

Arnold, J. G., Williams, J. R., Nicks, A. D., and Sammons, N. B.: SWRRB - A Basin Scale Simulation Model for Soil and Water ResourcesManagement, Texas A\&M University Press: College Station, TX, 1990.

Arnold, J. G., Srinivasan, R., Muttiah, R. S., and Williams, J. R.: Large area hydrologic modeling and assessment part I: model development, J. Am. Water Resour. As., 34, 73-89, doi:10.1111/j.1752-1688.1998.tb05961.x, 1998.

Beldring, S., Engeland, K., Roald, L. A., Slthun, N. R., and Voks, A.: Estimation of parameters in a distributed precipitationrunoff model for Norway, Hydrol. Earth Syst. Sci., 7, 304-316, doi:10.5194/hess-7-304-2003, 2003.

Blöschl, G., Reszler, C., and Komma, J.: A spatially distributed flash flood forecasting model, Environ. Modell. Softw., 23, 464478, doi:10.1016/j.envsoft.2007.06.010, 2008.

Das, T., Bárdossy, A., Zehe, E., and He, Y.: Comparison of conceptual model performance using different representations of spatial variability, J. Hydrol., 356, 106-118, doi:10.1016/j.jhydrol.2008.04.008, 2008.

Doherty, J.: Ground Water Model Calibration Using Pilot Points and Regularization, Ground Water, 41, 170-177, doi:10.1111/j.1745-6584.2003.tb02580.x, 2003.

Flügel, W.-A.: Delineating hydrological response units by geographical information system analyses for regional hydrological modelling using PRMS/MMS in the drainage basin of the River Bröl, Germany, Hydrol. Process., 9, 423-436, doi:10.1002/hyp.3360090313, 1995.

Fu, B. J.: Soil erosion and its control in the loess plateau of China, Soil use Manage., 5, 76-82, doi:10.1111/j.14752743.1989.tb00765.x, 1989.

Fu, B. J., Zhang, Q. J., Chen, L. D., Zhao, W. W., Gulinck, H., Liu, G. B., Yang, Q. K., and Zhu, Y. G.: Temporal change in land use and its relationship to slope degree and soil type in a small catchment on the Loess Plateau of China, Catena, 65, 41-48, doi:10.1016/j.catena.2005.07.005, 2006.

Fu, B. J., Wang, Y. F., Lu, Y. H., He, C. S., Chen, L. D., and Song, C. J.: The effects of land-use combinations on soil erosion: a case study in the Loess Plateau of China, Prog. Phys. Geog., 33, 793-804, doi:10.1177/0309133309350264, 2009.
Garen, D. C. and Moore, D. S.: Curve number hydrology in water quality modeling: uses, abuses, and future directions, J. Am. Water Resour. As., 41, 377-388, 2005.

Gustafson, E. J., Zollner, P. A., Sturtevant, B. R., He, H. S., and Mladenoff, D. J.: Influence of forest management alternatives and land type on susceptibility to fire in northern Wisconsin, USA, Landscape Ecol, 19, 327-341, doi:10.1023/B:LAND.0000030431.12912.7f, 2004.

Hellebrand, H. and van den Bos, R.: Investigating the use of spatial discretization of hydrological processes in conceptual rainfall runoff modelling: a case study for the meso-scale, Hydrol. Process., 22, 2943-2952, doi:10.1002/hyp.6909, 2008.

Hessel, R. and van Asch, T.: Modelling gully erosion for a small catchment on the Chinese Loess Plateau, Catena, 54, 131-146, doi:10.1016/s0341-8162(03)00061-4, 2003.

Huang, M. B., Gallichand, J., Wang, Z., and Goulet, M.: A modification to the Soil Conservation Service curve number method for steep slopes in the Loess Plateau of China, Hydrol. Process., 20, 579-589, doi:10.1002/hyp.5925, 2006.

Jha, M., Gassman, P. W., Secchi, S., Gu, R., and Arnold, J.: Effect of Watershed Subdivision on SWAT Flow, Sediment, and Nutrient Predictions, J. Am. Water Resour. As., 40, 811-825, doi:10.1111/j.1752-1688.2004.tb04460.x, 2004.

Kumar, R., Samaniego, L., and Attinger, S.: The effects of spatial discretization and model parameterization on the prediction of extreme runoff characteristics, J. Hydrol., 392, 54-69, doi:10.1016/j.jhydrol.2010.07.047, 2010.

Kupfer, J. A. and Franklin, S. B.: Evaluation of an ecological land type classification system, Natchez Trace State Forest, western Tennessee, USA, Landscape Urban. Plan., 49, 179-190, doi:10.1016/s0169-2046(00)00070-0, 2000.

Legesse, D., Vallet-Coulomb, C., and Gasse, F.: Hydrological response of a catchment to climate and land use changes in Tropical Africa: case study South Central Ethiopia, J. Hydrol., 275, 67-85, doi:10.1016/s0022-1694(03)00019-2, 2003.

Leprieur, C., Verstraete, M. M., and Pinty, B.: Evaluation of the performance of various vegetation indices to retrieve vegetation cover from AVHRR data, Remote Sensing Reviews, 10, 265284, 1994.

Li, Z., Liu, W. Z., Zhang, X. C., and Zheng, F. L.: Impacts of land use change and climate variability on hydrology in an agricultural catchment on the Loess Plateau of China, J. Hydrol., 377, 35-42, doi:10.1016/j.jhydrol.2009.08.007, 2009.

Ministry of Water Resources of the People's Republic of China: Standards for classification and gradation of soil erosion, China Hydroelectricity Press, Beijing, 1997 (in Chinese).

Mishra, S. K. and Singh, V. P.: Longterm hydrological simulation based on the Soil Conservation Service curve number, Hydrol. Process., 18, 1291-1313, 2004.

Nash, J. and Sutcliffe, J.: River flow forecasting through conceptual models part I-A discussion of principles, J. Hydrol., 10, 282-290, 1970.

NRCS: SCS National Engineering Handbook, Section 4, Soil Conservation Service, US Department of Agriculture, Washington, DC, 1972.

NRCS: Urban Hydrology for Small Watersheds, Technical Release 55 (TR-55), Natural Resources Conservation Service, US Department of Agriculture, Washington, DC, 1986.

Rykken, J. J., Capen, D. E., and Mahabir, S. P.: Ground bee- 
tles as indicators of land type diversity in the Green Mountains of Vermont, Conserv. Biol., 11, 522-530, doi:10.1046/j.15231739.1997.95336.x, 1997.

Saxton, K.: SPAW Soil Water Characteristics Version 6.02. 74. USDA Agricultural Research Service, Pullman, WA, 2002.

Tripathi, M. P., Raghuwanshi, N. S., and Rao, G. P.: Effect of watershed subdivision on simulation of water balance components, Hydrol. Process., 20, 1137-1156, doi:10.1002/hyp.5927, 2006.

Valentin, C., Poesen, J., and Li, Y.: Gully erosion: Impacts, factors and control, Catena, 63, 132-153, doi:10.1016/j.catena.2005.06.001, 2005.

Williams, J. R.: The EPIC model, in: Computer models of watershed hydrology, edited by: Singh, V. P., Water Resources Publications, Highlands Ranch, Colorado, 909-1000, 1995.
Williams, J. R., Nicks, A. D., and Arnold, J. G.: Simulator for Water Resources in Rural Basins, J. Hydraul. Eng.-ASCE, 111, 970986, 1985.

Winchell, M., Srinivasan, R., Di Luzio, M., and Arnold, J.: ArcSWAT Version 2009.93.5, Stone Environmental, Inc., Texas A\&M Spatial Sciences Laboratory, Blackland Research and Extension Center, 2010.

$\mathrm{Wu}$, Y. and Cheng, H.: Monitoring of gully erosion on the Loess Plateau of China using a global positioning system, Catena, 63, 154-166, 2005.

Zribi, M., Hégarat-Mascle, S. L., Taconet, O., Ciarletti, V., VidalMadjar, D., and Boussema, M. R.: Derivation of wild vegetation cover density in semi-arid regions: ERS2/SAR evaluation, Int. J. Remote Sens., 24, 1335-1352, 2003. 